\title{
無作為化比較試験による非小細胞肺癌切除例に対する 術後補助化学療法の有用性の検討
}

\author{
A Randomized Controlled Trial of Postoperative Adjuvant Chemotherapy \\ in Non-small Cell Lung Cancer
}

肺癌手術補助化学療法研究会 (中部)

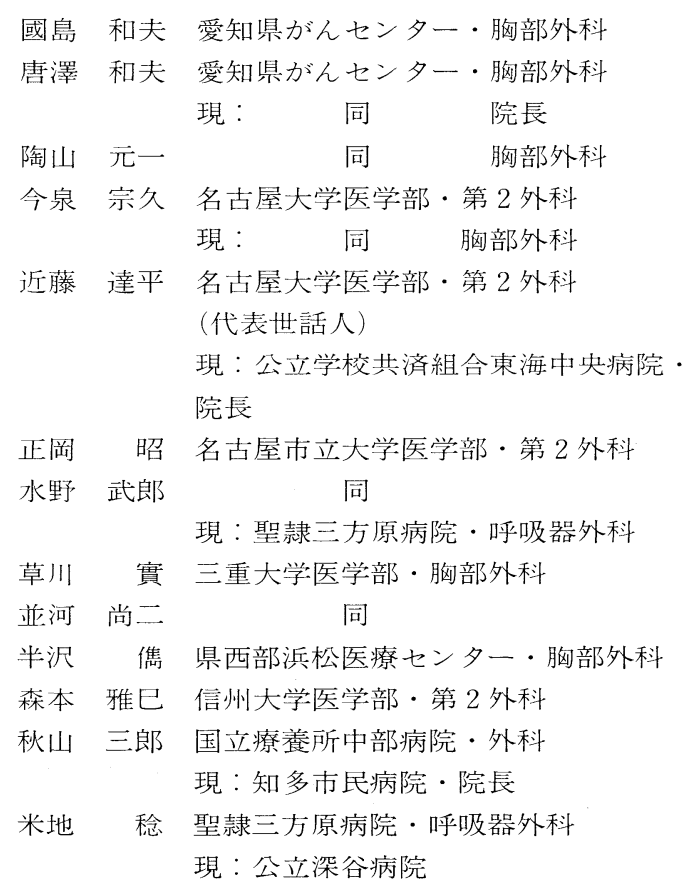

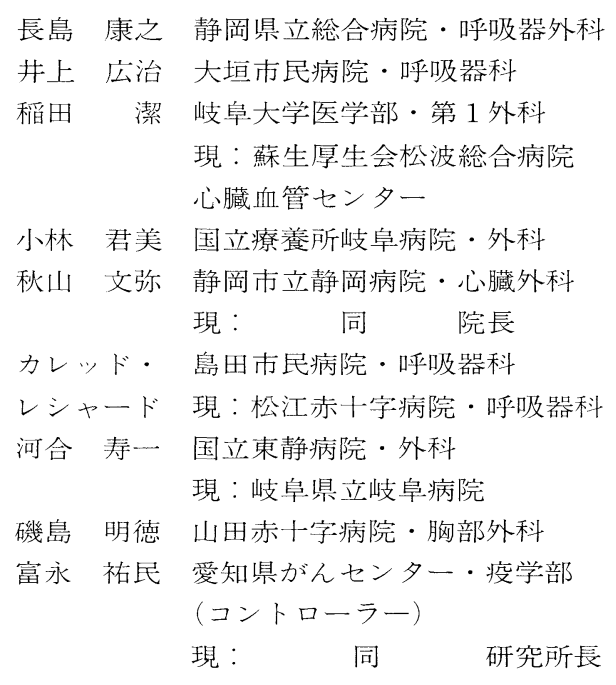

別刷請求先：

國島和夫

愛知県がんセンター 胸部外科

干464 名古屋市个種区鹿子殿 $1-1$

要旨: 肺癌手術補助化学療法研究会 (中部) は, 非小細胞肺癌切除例に対する術後補助化学療法 の有用性を評価するために, $\mathrm{MMC}+\mathrm{CPA}+\mathrm{FT}$ (A群) と手術単独 (B群)の 2 群による無 作為化比較試験を行った. 306例が登録され, そのうちの適格例282例を解析対象とした。 両群の 5 年生存率抢よU゙ 5 年無症候率には有意差は認めなかった。しかし, 予後因子の

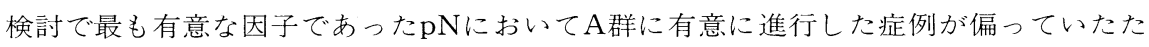
め, Coxの比例ハザードモデルにより補正を行った結果, 5 年生存率, 5 年無症候率と もにB群に比しA群が有意に良好であった. 以上により, 本術後補助化学療法の有用性が 示唆された。

〔肺癌 $32(4) ： 481 \sim 488,1992$ 〕

Key words : Non-small cell lung cancer, Postoperative adjuvant chemotherapy, Randomized controlled trial 
Fig. 1. Method of treatment.

\section{Group A}

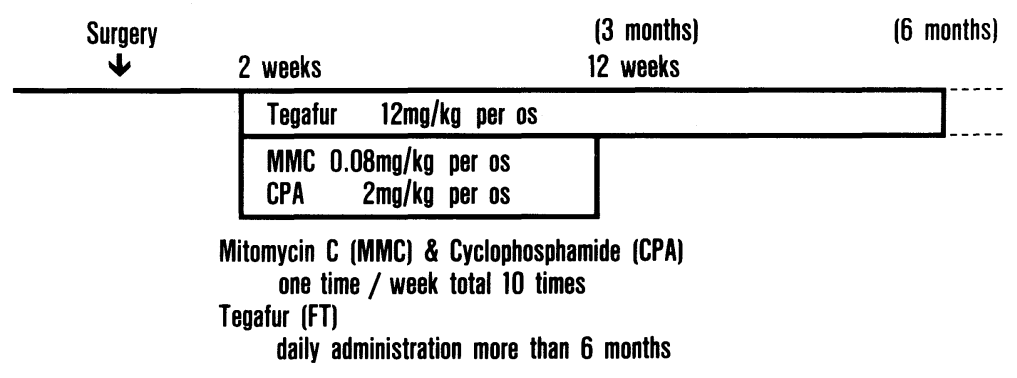

\section{Group B}

\section{I ・はじめに}

肺癌切除術に対する補助化学療法は, 肺癌手 術後遠隔転移による再発が多く 5 年生存率が $35 \%$ から $40 \%$ と不良であること，および，肺癌 が完全に切除された例で手術後 30 日以内に他の 疾患で死亡した202例の剖検で49例 (24\%)に遠

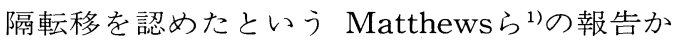
らみても，その必要性が考えられる。このため 過去より抗癌剤による術後補助化学療法が行わ れてきたが, 否定的な報告が多く，現在のとこ ろ標準治療となりうる療法が確立されていない のが現状である。

そこでわれわれは日本肺癌学会中部傘下の 20 施設による多施設共同研究会を組織し，非小細 胞肺癌切除例に対する術後補助化学療法の有用 性を評価するために，術後長期経口投与による MCF療法 (Mitomycin C + Cyclophosphamide +Tegafur) を研究群 (A群) とし, 手術単独群を 対照群 (B群)とした無作為化比較試験を実施し た.

本研究のprimary endpointは, 5 年生存率で あるが，5年無症候率および自他覚所見につい ても同時に検討を加えた。

\section{II. 対象と方法}

\section{1）対象および適格規準}

本研究は肺癌取扱い規約 (改定第 2 版) ${ }^{2)}$ に従 い，1982年11月より開始された。対象は，類表
皮癌, 腺癌, 大細胞癌, 腺表皮癌の原発性肺癌 とした。適格規準として以下の条件を採択した。 (1)治癒切除または準治癒切除の施行された症例, (2)Eastern Cooperative Oncology Group の Performans Status (P.S.)の Grade 0 2 の症 例, (3)75歳以下の症例, (4)手術前に癌治療を受 けた事のない症例, (5)同時性または異時性の重 複癌および多発癌を有さない症例。

\section{2 ) 治療法と割付}

登録された症例は，封筒法により $\mathrm{A}$ 群と B 群 に無作為に割り付けられた。A群には Mitomycin C (MMC) $0.08 \mathrm{mg} / \mathrm{kg}$ と Cyclophosphamide (CPA) 2mg/kgを経口で週 1 回合計 10 回投与し, 同時に Tegafur (FT) $12 \mathrm{mg} / \mathrm{kg}$ を 経ロで 6 カ月以上投与した (Fig. 1).

\section{3 ) 生死および再発の確認手段}

登録された症例は毎年, 年末に生死を確認し た.

再発の確認は，両群間に差を生じないように 注意しながら, 両群共に原則として, 術後 2 年 間は 3 力月毎に，それ以降は 6 力月毎に実施す る事とした。また，確認方法は主として，X線， $\mathrm{CT}$, 骨シンチ, 内視鏡, 生検, 喀痰細胞診等の 検查により行った。 また, 再発後の治療は, 主 治医の判断に一任することとした.

\section{4 ) 用語の解説および統計学的手法}

両群間の背景因子の均一性は, $\chi^{2}$ 検定ならび にU検定にて検討した. 
Table 1. Subjects.

\begin{tabular}{lrrr}
\hline \multicolumn{1}{c}{ Patients } & Group A & Group B & Total \\
\hline Total registered & 152 & 154 & 306 \\
Ineligible & 8 & 16 & 24 \\
(because of : ) & & & \\
$\quad$ incomplete resection & 4 & 6 & 10 \\
age & 1 & 5 & 6 \\
double cancers & 3 & 2 & 5 \\
$\quad$ small cell carcinoma & 0 & 2 & 2 \\
$\quad$ benign & 0 & 1 & 1 \\
Total evaluated & 144 & 138 & 282 \\
\hline
\end{tabular}

Table 2. Patient characteristics.

\begin{tabular}{lrrr}
\hline \multirow{2}{*}{ Characteristics } & \multicolumn{2}{c}{ Group } & \\
\cline { 2 - 3 } & A & B & \\
\hline Sex & & & \\
Male & 94 & 94 & $0.70\left(x^{2}\right)$ \\
Female & 50 & 44 & \\
Age(years) & & & \\
$<\quad 60$ & 60 & 51 & $0.48\left(x^{2}\right)$ \\
$\geqq 60$ & 84 & 87 & \\
pT & & & \\
1 & 63 & 70 & $0.19(\mathrm{U})$ \\
2 & 72 & 63 & \\
3 & 9 & 5 & \\
pN & & & \\
0 & 97 & 111 & $0.01(\mathrm{U})$ \\
1 & 31 & 20 & \\
2 & 16 & 7 & \\
Histology & & & \\
Adenocarcinoma (Ad) & 79 & 61 & $0.28\left(x^{2}\right)$ \\
Squamous cell carcinoma (Sq) & 55 & 64 & \\
Adenosquamous carcinoma & 7 & 7 & \\
Large cell carcinoma & 3 & 6 & \\
Curability & & & \\
Absolute & 105 & 118 & $0.01(\mathrm{U})$ \\
Relative & 39 & 20 & \\
P. S. & & & \\
0 & 121 & 114 & \\
1 & 23 & 23 & $0.73(\mathrm{U})$ \\
2 & 0 & 1 & \\
\hline
\end{tabular}

* $\mathrm{p}$ value according to $x^{2}$ test or $\mathrm{U}$ test

手術日から起算した生死確認までの期間を生 存期間とし, 得られた術後 5 年での累積生存率 を 5 年生存率として表わした。また，手術日か ら起算した再発確認日までの期間を無症候期間
Table 3. Prognostic significance of patient characteristics by Cox regression model.

\begin{tabular}{lrc}
\hline \multicolumn{1}{c}{ Prognostic factor } & $\begin{array}{c}\text { Regression } \\
\text { coefficient } \\
(\beta)\end{array}$ & $\begin{array}{l}\text { Significance } \\
\text { for regression } \\
\text { coefficient } \\
\text { (p value) }\end{array}$ \\
\hline pN (0:n0 1:n1 2:n2) & 0.7177 & $<0.001$ \\
Age (years) & 0.0290 & 0.0069 \\
pT (1:t1 2:t2 3:t3) & 0.1877 & 0.2400 \\
P.S. (0:P.S.0 1:P.S.1,2) & 0.2628 & 0.2313 \\
R (1:R1 2:R2 3:R3) & -0.2182 & 0.2531 \\
Sex (0:female 1:male) & 0.0022 & 0.9916 \\
Histology & & 0.4538 \\
Ad vs Sq & 0.1500 & 0.0084 \\
Ad vs others* & 0.7689 & \\
\hline
\end{tabular}

${ }^{*}$ adenosquamous cell carcinoma and large cell carcinoma

とし, 術後 5 年での無再発を 5 年生存率と同様

に 5 年無症候率として表わした.

5 年生存率および 5 年無症候率は KaplanMeier法 ${ }^{3)}$ で算出し， ログランク検定 ${ }^{4}$ 抢よび一 般化Wilcoxon検定5)で有意差検定を行った。さ らに，両群の背景因子の偏りの影響を補正した 5 年生存率, 5 年無症候率を推定するために, Coxの比例ハザードモデル6)により多変量解析 を行った。

\section{III. 結 果 \\ 1）研究期間および症例登録}

本研究の症例登録期間は1982年11月より 1985 年 5 月までの 2 年 7 カ月であり, 経過観察は 1990年12月31日まで実施された。

症例登録期間に306例が登録され，A群152例， B群154例が割り付けられた。適格規準に従い, 24 例 (7.8\%) が不適格例として除外され, 適格例 A群144例, B群138例が解析された (Table 1).

\section{2 ) 背景因子の検討}

性, 年齢, $\mathrm{pT}, \mathrm{pN}$, 組織型, 根治度掞よびP. S.について検討すると, $\mathrm{pN}$, 根治度について統 計学的に有意な偏りがみられ，A群に進行した 症例が多く含まれていた(Table 2).

また，Coxの比例八ザードモデルにより予後 因子の検討を行ったところ, $\mathrm{pN}$ が最も有意な子 後因子と考えられた (Table 3). 
Fig. 2. Five-year survival curves.

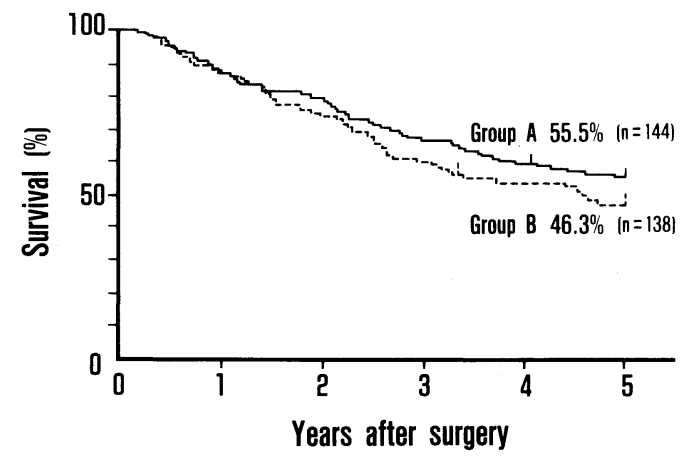

Fig. 4. Five-year survival curves adjusted for $\mathrm{pN}$ factor.

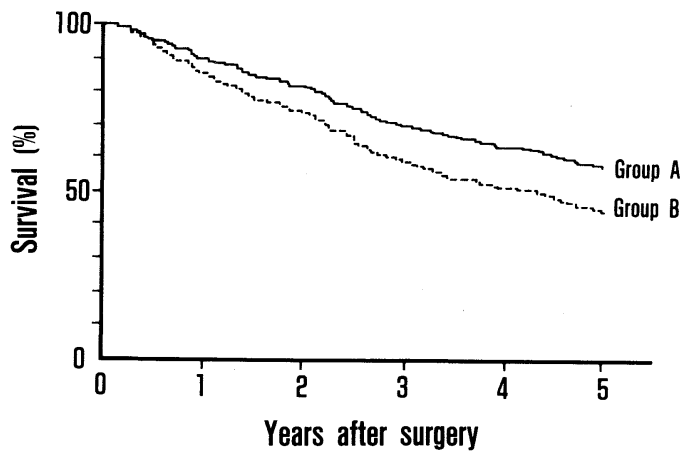

Cox regression model was fitted to the survival data of 282 patients, and the following regression model was obtained :

$\mathrm{h}(\mathrm{x} ; \mathrm{t})=\mathrm{ho}(\mathrm{t}) \cdot \exp (0.398$ group $+0.713 \mathrm{pN})$

model fit : $\chi^{2}=39.59$ (D.F. $=2$ ) $\mathrm{p}<0.001$

Levels of significance for patient characteristics were determined for the group $(\mathrm{p}=0.022)$ and for $\mathrm{pN}(\mathrm{p}<$ 0.001).

\section{3 ）服薬状況}

患者体重を $50 \mathrm{~kg}$ と仮定すると, A群の目標投 与量は, MMC $40.0 \mathrm{mg}, \mathrm{CPA} 1000.0 \mathrm{mg}, \mathrm{FT}$ $96.0 \mathrm{~g}$ となるが, $\mathrm{A}$ 群における各々の薬剤の平均 投与量は, MMC $38.4 \mathrm{mg}$, CPA $974.7 \mathrm{mg}$, FT $126.3 \mathrm{~g}$ であった。また，本治療の期間中は放射 線療法, 免疫療法等の治療は一切施行されなか った。

\section{4 ）全症例における 5 年生存率および 5 年無症 候率}

全症例が術後 5 年間経過観察され, A群の 1 ～ 5 年生存率は各々 $86.8 \%, 79.2 \%, 65.3 \%$, $59.7 \%, 55.5 \%$ で，B群では $87.0 \%, 73.9 \%$,
Fig. 3. Five-year disease-free survival curves.

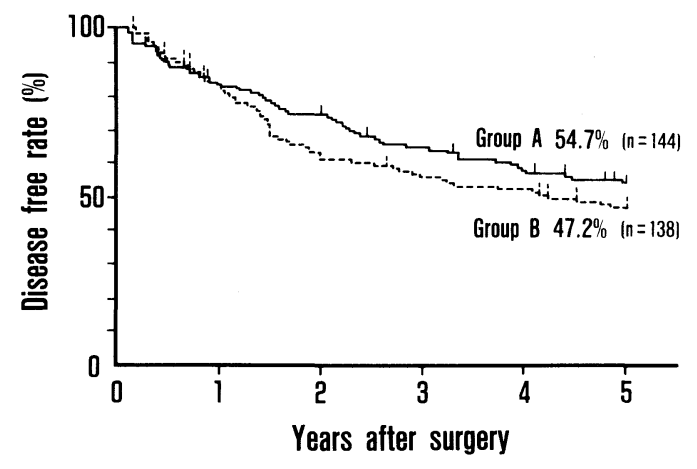

Fig. 5. Five-year disease-free survival curves adjusted for $\mathrm{pN}$ factor.

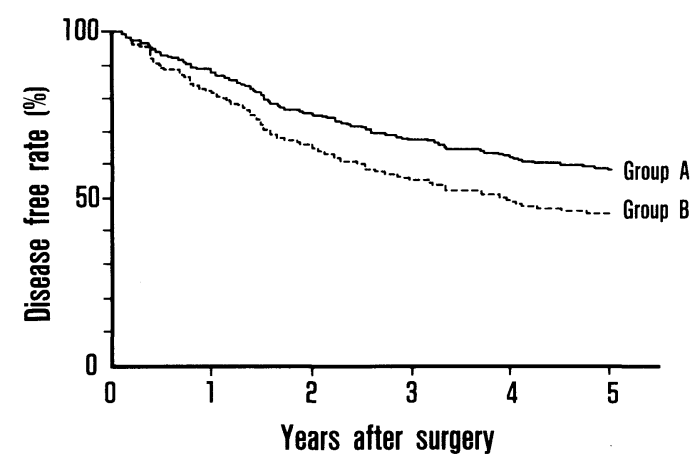

Cox regression model was fitted to the disease-free survival data of 282 patients, and the following regression model was obtained :

$\mathrm{h}(\mathrm{x} ; \mathrm{t})=\mathrm{ho}(\mathrm{t}) \cdot \exp (0.416 \mathrm{group}+0.848 \mathrm{pN})$

model fit : $\chi^{2}=59.91$ (D.F. $\left.=2\right) \mathrm{p}<0.001$

Levels of significance for patient characteristics were determined for the group $(\mathrm{p}=0.020)$ and for $\mathrm{pN}(\mathrm{p}<$ $0.001)$.

60.1\%，54.3\%，46.3\%であり，画群間に有意 差は認めなかった(Fig. 2).

また，A群の 1 〜 年無症候率は各々 $83.8 \%$, $74.3 \%, 64.6 \%, 57.8 \%, 54.7 \%$ で，B群では $83.7 \%, 61.6 \%, 56.1 \%, 52.2 \%, 47.2 \%$ あ り, 雨群間に有意差は認められなかった(Fig. 3).

5 ) 補正 5 年生存率および補正 5 年無症候率の 推定

前述のごとく, 予後に対する重要な因子であ

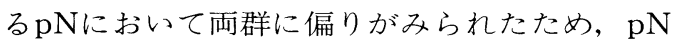
による補正を行ったところ，5年生存率では $\mathrm{p}=0.022$ でA群が有意に良好であった(Fig. 4). 
Table 4. Five-year survival rates.

\begin{tabular}{|c|c|c|c|c|c|c|}
\hline \multirow[b]{2}{*}{ Group: } & \multicolumn{2}{|c|}{$\begin{array}{l}\text { No. of } \\
\text { patients }\end{array}$} & \multicolumn{2}{|c|}{$\begin{array}{c}5 \text {-yr } \\
\text { survival(\%) }\end{array}$} & \multicolumn{2}{|c|}{$\mathrm{p}$ value* } \\
\hline & A & B & A & B & L.R. & G.W. \\
\hline Total evaluated & 144 & 138 & 55.5 & 46.3 & 0.147 & 0.192 \\
\hline \multicolumn{7}{|l|}{$\mathrm{pT}$} \\
\hline 1 & 63 & 70 & 61.9 & 55.4 & 0.378 & 0.320 \\
\hline 2 & 72 & 63 & 52.7 & 38.1 & 0.174 & 0.332 \\
\hline 3 & 9 & 5 & 33.3 & 20.0 & 0.555 & 0.492 \\
\hline \multicolumn{7}{|l|}{$\mathrm{pN}$} \\
\hline 0 & 97 & 111 & 67.0 & 51.4 & 0.023 & 0.025 \\
\hline 1 & 31 & 20 & 38.7 & 35.0 & 0.734 & 0.781 \\
\hline 2 & 16 & 7 & 18.8 & 0.0 & 0.418 & 0.791 \\
\hline \multicolumn{7}{|l|}{ Histology } \\
\hline Ad & 79 & 61 & 59.4 & 50.8 & 0.324 & 0.350 \\
\hline $\mathrm{Sq}$ & 55 & 64 & 54.6 & 45.1 & 0.314 & 0.334 \\
\hline \multicolumn{7}{|l|}{ pStage } \\
\hline I & 103 & 115 & 64.0 & 52.9 & 0.094 & 0.096 \\
\hline II & 20 & 11 & 45.0 & 18.2 & 0.184 & 0.305 \\
\hline III & 21 & 12 & 23.8 & 8.3 & 0.337 & 0.510 \\
\hline \multicolumn{7}{|l|}{ Curability } \\
\hline Absolute & 105 & 118 & 64.7 & 51.6 & 0.043 & 0.042 \\
\hline Relative & 39 & 20 & 30.8 & 15.0 & 0.039 & 0.748 \\
\hline
\end{tabular}

また， 5 年無症候率においても $\mathrm{p}=0.020$ でA群 が有意に良好であった(Fig. 5)。

6 ）後層別による 5 年生存率，5年無症候率 $\mathrm{pN}_{0}$ 症例の 5 年生存率は $\mathrm{A}$ 群 $67.0 \%, \mathrm{~B}$ 群 $51.4 \%$ であり $\mathrm{A}$ 群の方が有意に良好であった。 更に, 根治度においても治瘾切除例で $\mathrm{A}$ 群 64.7\%，B群 51.6\%でありA群の方がいずれも $\mathrm{p}<0.05$ で有意に良好であったが, その他の因 子では両群間に有意な差は認められなかった (Table 4)。また, $\mathrm{pN}_{0}$ 症例の 5 年無症候率は $\mathrm{A}$ 群 $71.3 \%$, B群 $55.7 \%$ であり A群の方が $<<0.05$ で有意に良好であったが，その他の因子では両 群間に有意な差はなかった(Table 5).

\section{7 ）自他覚所見および臨床検査値異常}

自他覚所見および臨床検査值異常の発現率は, $\mathrm{A}$ 群B群各々 $46.5 \%, 23.2 \%$ で, 食欲不振, 白血 球減少等がA群に多くみられたが, 重篤なもの は認められなかった (Table 6)。また, 自他覚所 見および臨床検查值異常によるA群の中止例は 16例であった $(11.1 \%)$.
Table 5. Five-year disease-free survival rates.

\begin{tabular}{|c|c|c|c|c|c|c|}
\hline \multirow[b]{2}{*}{ Group: } & \multicolumn{2}{|c|}{$\begin{array}{l}\text { No. of } \\
\text { patients }\end{array}$} & \multicolumn{2}{|c|}{$\begin{array}{c}5-y r \\
\text { disease-free } \\
\text { survival }(\%)\end{array}$} & \multicolumn{2}{|c|}{$\mathrm{p}$ value* } \\
\hline & A & B & A & $B$ & L.R. & G.W. \\
\hline Total evaluated & 144 & 138 & 54.7 & 47.2 & 0.216 & 0.252 \\
\hline \multicolumn{7}{|l|}{ pT } \\
\hline 1 & 63 & 70 & 63.5 & 57.7 & 0.570 & 0.623 \\
\hline 2 & 72 & 63 & 51.1 & 39.8 & 0.186 & 0.255 \\
\hline 3 & 9 & 5 & 22.2 & 0.0 & 0.105 & 0.242 \\
\hline \multicolumn{7}{|l|}{$\mathrm{pN}$} \\
\hline 0 & 97 & 111 & 71.3 & 55.7 & 0.021 & 0.020 \\
\hline 1 & 31 & 20 & 22.6 & 15.0 & 0.478 & 0.692 \\
\hline 2 & 16 & 7 & 20.2 & - & 0.542 & 0.597 \\
\hline \multicolumn{7}{|l|}{ Histology } \\
\hline Ad & 79 & 61 & 53.9 & 51.3 & 0.736 & 0.771 \\
\hline $\mathrm{Sq}$ & 55 & 64 & 62.6 & 46.8 & 0.098 & 0.103 \\
\hline \multicolumn{7}{|l|}{ pStage } \\
\hline I & 103 & 115 & 67.9 & 56.3 & 0.088 & 0.094 \\
\hline II & 20 & 11 & 25.0 & 0.0 & 0.052 & 0.220 \\
\hline III & 21 & 12 & 20.1 & - & 0.163 & 0.243 \\
\hline \multicolumn{7}{|l|}{ Curability } \\
\hline Absolute & 105 & 118 & 64.1 & 55.0 & 0.159 & 0.150 \\
\hline Relative & 39 & 20 & 28.8 & 0.0 & 0.028 & 0.204 \\
\hline
\end{tabular}

Table 6. Distribution of objective and subjective symptoms.

\begin{tabular}{lcc}
\hline \multicolumn{1}{c}{ Patients } & Group A (\%) & Group B (\%) \\
\hline Total evaluated & \multicolumn{1}{c}{144} & \multicolumn{1}{c}{138} \\
Total of unusual cases* & $67(46.5)$ & $32(23.2)$ \\
Chemotherapy interrupted & $16(11.1)$ & $0(0.0)$ \\
\hline${ }^{*}$ Unusual cases: & & \\
WBC $\left(\leqq 3000 / \mathrm{mm}^{3}\right)$ & $9(6.3)$ & $1(0.7)$ \\
$\mathrm{RBC}\left(\leqq 300 \times 10^{4} / \mathrm{mm}^{3}\right)$ & $1(0.7)$ & $0(0.0)$ \\
PLT $\left(\leqq 10 \times 10^{4} / \mathrm{mm}^{3}\right)$ & $3(2.1)$ & $0(0.0)$ \\
GOT $(\geqq 100 \mathrm{U})$ & $8(5.6)$ & $5(3.6)$ \\
GPT $(\geqq 100 \mathrm{U})$ & $9(6.3)$ & $7(5.1)$ \\
LDH $(\geqq 500 \mathrm{U})$ & $4(2.8)$ & $2(1.4)$ \\
Anorexia & $36(25.0)$ & $22(15.9)$ \\
Nausea/Vomiting & $11(7.6)$ & $7(5.1)$ \\
Diarrhea & $3(2.1)$ & $1(0.7)$ \\
Stomatitis & $2(1.4)$ & $1(0.7)$ \\
General malaise & $25(17.4)$ & $24(17.4)$ \\
Pigmentation & $7(0.9)$ & $0(0.0)$ \\
\hline
\end{tabular}




\section{IV. 考察}

非小細胞肺癌切除例における標準的術後補助 化学療法は, 現在のところまだ確立されていな (7),8). そこで本研究においては, 非小細胞肺癌 に対する術後補助化学療法を探索する目的で, 手術単独群を対照とし, 術後MMC, CPA, FT の併用化学療法群を研究群とした無作為化比較 試験を実施した。

MMC, CPA，FTはいずれも国内における臨 床試験で, 非小細胞肺癌に対する抗腫瘍効果が 確認された薬剤であり，単剂での有効率は MMC 12〜45\%, CPA 0〜17\%であり，FTは $7.8 \%$ である事が報告されている9910). MMC, CPAおよびFTの 3 剂併用による抗腫瘍効果に 関する評価は得られていないが，参考とすべき 報告として, Cisplatin(CDDP) $15 \mathrm{mg} / \mathrm{m}^{2}+\mathrm{FT}$ $3 \mathrm{~g} / \mathrm{m}^{2}+$ Doxorubicin (ADM) $20 \mathrm{mg} / \mathrm{m}^{2}+$ CPA $500 \mathrm{mg} / \mathrm{m}^{2} て ゙ 31 \%$ の奏効率であったとするValdiviesoら ${ }^{11)}$ 報告や, ADM $40 \mathrm{mg} / \mathrm{m}^{2}+\mathrm{MMC}$ $10 \mathrm{mg} / \mathrm{m}^{2}+\mathrm{FT} 500 \mathrm{mg} / \mathrm{m}^{2}$ の併用で $25 \%$ の奏効 率を示したSalvatiら ${ }^{12)}$ 報告などがある。

一方, 術後補助化学療法にCPAを組み入れた例 としては, 無作為化比較試験でないものでは,

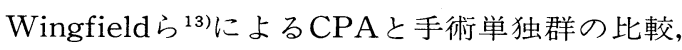
Newmanら ${ }^{14)} に よ る \mathrm{II}$ 期を対象としたCPA+ $\mathrm{ADM}+$ Methotrexate $(\mathrm{MTX})$ および放射線併 用群と手術単独群との比較などいずれも有効と する報告がある。また，無作為化比較試験では Holmes ${ }^{15)} に よ る$ 腺癌と大細胞癌の II 期 III 期 を対象とした $\mathrm{CPA}+\mathrm{ADM}+\mathrm{CDDP}$ 的G+ Levamisoleの比較で無症候率において有意に 良好であったとする報告などがある，更に，術 後長期にわたる補助化学療法を考えた場合, 副
作用が少なく経口投与可能な薬剂が理想と考え， 共同研究開始の1982年11月の時点で, 日常汎用 されていた上記 3 㓮を選択した。

今回の結果では, 5 年生存率, 5 年無症候率 において全症例では補助化学療法施行群の方が 良好な成績であったが, 統計学的に有意差は得 られなかった。しかし，背景因子において，最

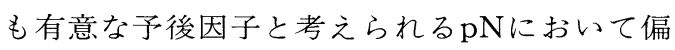
クがみられ，A群に進行した症例が多かった，そ こで, Coxの比例ハザードモデルによりこの因 子について補正を行った結果，5年生存率およ び 5 年無症候率ともに有意な差が得られ, 術後 補助化学療法の有用性が示唆された。更に, 今 回のMCF療法は重篤な副作用は認められず, ま た副作用による中止例も少なく，長期にわたり 施行し易い療法と考えられた。

肺癌の術後予後の悪い理由の一つに, 完全に 切除し得た症例においても不顕性の微小遠隔転 移により，比較的早期に再発が起こる事が考え られる。本研究の 5 年生存率に関する成績から, 術後長期にわたるMCF療法は非小細胞肺癌の $\mathrm{pN}_{0}$, 治癒切除例において延命効果が示唆され, 本療法の有用性が伺われた。更に，5年無症候 率の成績から検討すると, 5 年生存率と同様 $\mathrm{pN}_{0}$ 症例において有意に優れており，一つの可 能性として, 本療法は非小細胞肺癌の $\mathrm{pN}_{0}$ 症例 に対して術後の微小転移を抑制し延命につなが ったものと考えられる.しかしながら, 本研究 においては前述のごとく患者背景に偏りがあり， また適格例全例で得られた結論でないため, 今 後 $\mathrm{pN}_{0}$ の非小細胞肺癌切除例を対象としたconfirmative randomized controlled trialを実施 すべきと考える.

\section{文献}

1) Matthews MJ, Kanhouwa S, Pickren J, et al.: Frequency of residual and metastatic tumor in patients undergoing curative surgical resection for lung cancer. Cancer Chemother Rep Part 3, $4: 63-67,1973$.

2) 日本肺癌学会: 肺癌取扱い規約 (改定第 2 版),
金原出版，東京，1982.

3) Kaplan EL, Meier P : Nonparametric estimation from incomplete observation. J Am Statist Assoc 53 : 457-481, 1958.

4) Peto R, Pike MC, Armitage P, et al.: Design and analysis of randomized clinical trials 
requiring prolonged observation of each patient. II. Analysis and Examples. $\mathrm{Br} \mathrm{J}$ Cancer 35 : 1-39, 1977.

5) Gehan EA : A generalized Wilcoxon test for compairing arbitrarily singly-censored samples. Biometrika 52 : 203-223, 1965.

6) Cox DR : Regression models and life-tables. J Royal Statist Soc Series B 34:187-220, 1972.

7) Marangolo $M$ and Fiorentini $G$ : Adjuvant chemotherapy of non-small cell lung cancer. A review. Semin Oncol 15(Supple 7) : 13-17, 1988.

8) Holmes EC, Bleehen NM and Le Chevalier $\mathrm{T}$, et al.: Post operative adjuvant treatments for non-small cell lung cancers: A consensus report. Lung Cancer 7:11-13, 1991.

9) S $\phi$ rensen JB, Clerici M, Hansen HH : Single -agent chemotherapy for advanced adenocarcinoma of the lung. Cancer chemother Pharmacol 21: 89-102, 1988.

10）仁井谷久暢：肺癌，フトラフール一癌化学療法 におけるその役割をめぐって一。蟹書房，東
京, 292頁, 1983.

11) Valdivieso M, Burgess MA, Ewer MS, et al.: Increased therapeutic index of weekly doxorubicin in the therapy of non-small cell lung cancer : A prospective, randomized study. JCO $2: 207-214,1984$.

12) Salvati F, Cruciani AR, Marinis AD : Ftorafur, adriamycin and mitomycin C (FAM II) for extensive bronchogenic adenocarcinoma and large cell carcinoma. Jpn J Clin Oncol, $14: 3-6,1984$.

13) Wingfield HV : Combined surgery and chemotherapy for carcinoma of the bronchus. Lancet $7644: 470-471,1970$.

14) Newman SB, DeMeester TR, Golomb HM, et al. : Treatment of modified Stage II (T1N1 M0, T2N1M0) non-small cell bronchogenic carcinoma. J Thorac Cardiovasc Surg 86 : 180-185, 1983.

15) Holmes EC, Gail M: Surgical adjuvant therapy for stage II and stage III adenocarcinoma and large cell undifferentiated carcinoma. J Clin Oncol $4: 710-715,1986$. 


\title{
A Randomized Controlled Trial of Postoperative Adjuvant Chemotherapy in Non-small Cell Lung Cancer
}

\author{
Kazuo Kunishima, et al \\ The Study Group of Adjuvant Chemotherapy \\ for Lung Cancer (Chubu, Japan)
}

The study group of adjuvant chemotherapy for lung cancer (Chubu, Japan) carried out a randomized trial to examine the effectiveness of postoperative adjuvant chemotherapy in patients with resected non-small cell lung cancer. Patients were assigned either to a group receiving postoperative treatment with $\mathrm{MMC}+\mathrm{CPA}+\mathrm{FT}$ (group A) or a group undergoing surgery only (group B). Out of 306 registered cases, analyses were carried out on 282 eligible cases. No statistical differences were seen between the two groups with regard to 5-year survival rate or 5-year disease-free rate. Since pN was considered the most significant prognostic factor and there were more patients with advanced $\mathrm{pN}$ in group $\mathrm{A}$, additional analysis was done using the Cox proportional hazard model. A corrected comparison of both groups revealed that group A had a significantly higher 5-year survival rate and 5-year disease-free survival rate than group B.

These results suggest that this postoperative adjuvant chemotherapy is effective for patients with non-small cell lung cancer. 